\title{
(2) OPEN ACCESS \\ Prevalence and severity of periodontal disease among Spanish military personnel
}

\author{
Millán Bárcena García, J M Cobo Plana, ${ }^{2}$ P I Arcos González ${ }^{3}$
}

'Department of Dentistry. Military Army Base 'Conde de Gazola', Government of Spain Ministry of Defense, Ferral del Bernesga, León, Spain ${ }^{2}$ Department of Surgery and Medical and Surgical Specialties, University of Oviedo Faculty of Medicine and Health Sciences, Oviedo, Asturias, Spain ${ }^{3}$ Department of Medicine, University of Oviedo Faculty of Medicine and Health Sciences, Oviedo, Asturias, Spain

\section{Correspondence to}

Capt Millán Bárcena García Department of Dentistry. Military Army Base "Conde de Gazola", Government of Spain Ministry of Defense, Ferral del Bernesga, León 24260, Spain; millanbg@hotmail.com

Received 27 January 2020 Revised 10 February 2020 Accepted 11 February 2020
Check for updates

(c) Author(s) (or their employer(s)) 2020. Re-use permitted under CC BY-NC. No commercial re-use. See rights and permissions. Published by BMJ.

To cite: Bárcena García M, Cobo Plana JM, Arcos González PI. BMJ Mil Health Epub ahead of print: [please include Day Month Year]. doi:10.1136/

bmjmilitary-2020-001419

\section{ABSTRACT}

Introduction Periodontal disease ranges from simple gums inflammation to major damage to the periodontal tissues, even losing teeth. Severe periodontitis has a world overall prevalence of $11.2 \%$. These are evaluated with periodontal probes and oral epidemiological indices. Our aim is to estimate the prevalence and severity of periodontal disease of a Spanish military population according to the 2013 WHO criteria.

Methods Observational study of prevalence carried out in a representative random sample of 221 military staff from the Spanish Army base 'Conde de Gazola'. Prevalence was estimated by calculating the Community Periodontal Index modified, loss of attachment, Plaque Index and Gingival Bleeding Index measured with a thirdgeneration electronic 'Pa-on' periodontal probe.

Results Averages of probing depth, recession and clinical attachment level were 2.17, 0.19 and $2.36 \mathrm{~mm}$. Plaque and gingival bleeding indices were $71 \%$ and $40.3 \%$. All subjects bled in some tooth after probing. $3.6 \%$ of subjects had no periodontal pockets, $58.8 \%$ mild periodontal pockets and $37.1 \%$ severe periodontal pockets. All had some loss of attachment, $52 \%$ mild loss of attachment and $47.5 \%$ severe loss of attachment. Teeth present with and without bleeding were 24.4 $(86.5 \%)$ and 3.6 (13.1\%). $28 \%$ of teeth had periodontal pockets and $40.4 \%$ loss of attachment. Sextant averages with periodontal pockets and loss of attachment were 2.79 and 3.56 .

Conclusions Our plaque and gingival bleeding indices were high and we found a higher prevalence and severity of periodontal disease than other Spanish and foreign military populations. This could be related to differences in context, life habits and insufficient dental hygiene.

\section{INTRODUCTION}

Periodontal disease is a chronic non-communicable disease defined as any disorder of the tissues that surround and support the teeth, usually involving inflammatory alterations induced by biofilmforming bacteria in the periodontium. ${ }^{1}$ Its evaluation is performed with a periodontal probe and the prevalence in a population is determined by measuring oral hygiene, gingival and periodontal indices. Periodontitis has been reported in military populations throughout history with a variable prevalence due, among other reasons, to the absence of a uniform measurement methodology and sociodemographic differences.

During the First World War the term Trench Mouth, currently called necrotising periodontitis, was introduced because it was a common pathological periodontal condition among soldiers. ${ }^{2}$

\section{Key messages}

Periodontal disease is one of the most common chronic non-communicable disease worldwide, being the main cause of tooth loss.

- Any periodontal pathology in military personnel can cause a dental casualty, affecting the operation of the units.

- Studies in military populations are scarce and show great variability in the prevalence and severity of periodontitis due to difficulties in comparison between authors.

- The prevention of periodontal disease in Armed Forces is important to reduce oral pathologies both in national territory and in areas of operations.

Military professionals are a high-risk group for oral diseases because they work under specific physical, psychological and environmental conditions. ${ }^{3}$ Therefore, promoting its periodontal health is not only an important component of general health but also for military preparedness, representing a part of the strategic orientation of each country. ${ }^{4}$

The aim of this study was to estimate the prevalence and severity of periodontal disease in a representative sample of the Spanish military population according to the 2013 criteria of the WHO.

\section{METHODS}

This was a cross-sectional observational prevalence study in a representative random sample of military personnel, conducted between October 2015 and May 2016, to assess periodontal health status. From the study population (N) of 1297 military personnel assigned to the 'Conde de Gazola' Army base (León), between 25 and 57 years of age, including all military positions from soldier to Brigadier general, a representative sample (n) of 221 individuals-189 men and 32 women-was selected using a randomisation software. This military facility houses several military units, including the Campaign Artillery Command and Emergency Intervention battalion, and its organisation is almost completely similar to other Spanish bases in terms of Army staff and structure.

The criteria established by the WHO in 2013 for the study of oral health in a population were followed, in particular the section referring to the study of periodontal status using the Community Periodontal Index modified (CPI modified) ${ }^{5}$ for measuring gingival bleeding and periodontal pockets. Loss of attachment was also evaluated. 
Additionally, the Plaque Index, ${ }^{6}$ the Gingival Bleeding Index, ${ }^{7}$ mean probing depth, gingival recession and clinical attachment level were examined in each individual. The third generation electronic 'Pa-on' periodontal probe (Orangedental $\mathrm{GmbH}$ \& Co KG, Germany) was used as a measuring instrument as it provides greater precision and accuracy in periodontal examinations.

Examinations were performed by a single examiner, to avoid interexaminer bias, by exploring six sites per tooth of all teeth present in the mouth, including third molars. As the values calculated by the probe vary in $0.1 \mathrm{~mm}$ increments, the pathological cut-off determined by the WHO for probing depth and clinical attachment level was set at $3.5 \mathrm{~mm}$.

Gingival bleeding was recorded as the absence or presence of bleeding on probing for each tooth. Probing depth was individually classified according to the absence or presence of mild pockets $(4$ to $5 \mathrm{~mm}$ ) and severe pockets $(\geq 6 \mathrm{~mm})$, according to the highest value obtained after six periodontal probings for each tooth. Gingival health was assessed by calculating the number and percentage of individuals and teeth with and without bleeding on probing. Furthermore, the prevalence of subjects with periodontal pockets was determined by calculating the number and percentage of individuals without pockets, with superficial pockets and with deep pockets, according to the maximum severity found for each individual after examining all teeth. The severity of periodontitis was determined according to the number and percentage of teeth present in the mouth without pockets, with superficial pockets and with deep pockets. Finally, the number and percentage of excluded and missing teeth were also counted.

To compare our results with other studies we also calculated the $\mathrm{CPI},{ }^{8}$ recording the periodontal status by sextants. By transforming the results of the CPI modified to the CPI, in our study, we did not record the presence of calculus, and gingival bleeding was analysed separately from the presence of periodontal pockets. Therefore, individuals were classified into three categories: without periodontal pockets, with superficial pockets and with deep pockets.

Finally, to estimate cumulative periodontal destruction, the clinical attachment level was calculated by selecting index teeth and dividing the mouth into sextants for examination. The extent of loss of attachment was stratified into the following five levels according to the millimetres lost: 0 to $3 \mathrm{~mm}, 4$ to $5 \mathrm{~mm}$, 6 to $8 \mathrm{~mm}, 9$ to $11 \mathrm{~mm}$ and $12 \mathrm{~mm}$ or more. The prevalence of loss of attachment was measured by calculating the number and percentage of individuals with the maximum value obtained in this variable after analysing the six sextants. Likewise, severity of loss of attachment was estimated according to the mean of sextants with loss of attachment. Finally, the mean of excluded and unrecorded sextants was included.

In the descriptive statistical analysis, for continuous variables, the arithmetic mean was calculated as a measure of central tendency, and the SE of the mean and SD were calculated as dispersion measures. For categorical variables, the frequency distribution was calculated according to the results of the survey variables and results obtained with the periodontal probe. For the inferential analysis, the correlation between probing depth, clinical attachment level, plaque index and the bleeding on probing index was calculated using Pearson, Kendall and Spearman correlations. Dispersion diagrams were plotted for those variables whose relationship was significant.

The results found in the present study were compared with those of similar studies at national and global levels in the military population, despite its complexity.
Table 1 Periodontal status according to the highest score found after examining all sites of all teeth

\begin{tabular}{llccl}
\hline & & $\begin{array}{l}\text { Participants } \\
\mathbf{n}(\%)\end{array}$ & $\begin{array}{l}\text { Teeth present } \\
\mathbf{n}(\%)\end{array}$ & $\begin{array}{l}\text { Sextants } \\
(\mathbf{x})\end{array}$ \\
\hline Bleeding on & Absence & $0(0)$ & $3.6(13.1)$ & - \\
probing & Presence & $220(99.5)$ & $24.4(86.5)$ & - \\
Periodontal & $0-3 \mathrm{~mm}$ & $8(3.6)$ & $20(71.5)$ & - \\
pockets & $4-5 \mathrm{~mm}$ & $130(58.8)$ & $7.1(25)$ & 2.37 \\
& $\geq 6 \mathrm{~mm}$ & $82(37.1)$ & $0.9(3)$ & 0.42 \\
& $\geq 4 \mathrm{~mm}$ & $212(95.9)$ & $7.9(28)$ & 2.79 \\
Loss of & $0-3 \mathrm{~mm}$ & $0(0)$ & $16.7(59.2)$ & 2.36 \\
attachment & $4-5 \mathrm{~mm}$ & $115(52)$ & $9.8(35)$ & - \\
& $\geq 6 \mathrm{~mm}$ & $105(47.5)$ & $1.5(5.3)$ & - \\
& $\geq 4 \mathrm{~mm}$ & $220(99.5)$ & $11.3(40.3)$ & 3.56 \\
\hline
\end{tabular}

\section{RESULTS}

The mean probing depth, gingival recession and clinical attachment level were 2.17 (SEM=0.02; SD=0.36), $0.19(\mathrm{SEM}=0.01$; $\mathrm{SD}=0.21)$ and $2.36(\mathrm{SEM}=0.03 ; \mathrm{SD}=0.45)$, respectively. The Plaque Index was $71 \%(\mathrm{SEM}=0.72 ; \mathrm{SD}=10.74)$, and the Gingival Bleeding Index was 40.3\% (SEM=1.16; SD=17.14). Mean number and percentages of teeth present, missing and excluded per person were 28 (87.4\%), 3.7 (11.6\%), and 0.3 (1\%), respectively.

Table 1 shows the CPI modified and loss of attachment results, calculated according to the highest score found after examining six sites per tooth in all teeth present in the mouth.

All subjects studied showed bleeding on probing in some tooth and 24\% in all teeth. The number and percentage of teeth present with gingival bleeding were 24.4 (86.5\%). Overall, 95.9\% and $99.5 \%$ of the population studied had some periodontal pocket and loss of attachment, respectively.

Severity of periodontitis according to the percentage of teeth present with periodontal pockets and loss of attachment showed that $28 \%$ and $40.3 \%$ had periodontal pockets and some degree of loss of attachment, respectively. Furthermore, the number of sextants with periodontal pockets and loss of attachment resulted in a mean of 2.79 and 3.56 sextants, respectively. The mean of excluded sextants was 0.08 , and there were no unrecorded sextants.

Otherwise, according to the CPI and the highest score obtained after exploring the six sextants in each individual, the prevalence of subjects with periodontal pockets was 91\% (mild: $63.8 \%$ and severe: $27.2 \%$ ) while $97.2 \%$ showed some degree of loss of attachment, (4 to $5 \mathrm{~mm}: 62.4 \%$ and $\geq 6 \mathrm{~mm}$ : $34.8 \%$ ).

Figures 1-3 show the results of the correlation analysis between Plaque Index and bleeding on probing, probing depth and bleeding on probing and clinical attachment level and bleeding on probing. There was a significant correlation for the three cases $(R=0.383 ; \mathrm{p}=0.000),(\mathrm{R}=0.453 ; \mathrm{p}=0.000)$, $(\mathrm{R}=0.361 ; \mathrm{p}=0.000)$, respectively; in the non-parametric analysis, the correlation was also significant (Kendall's tau $=0.258$; $\mathrm{p}=0.000$ ) (Spearman's rho $=0.355 ; \mathrm{p}=0.000$ ); (Kendall's tau $=0.282 ; \mathrm{p}=0.000) \quad$ (Spearman's rho $=0.407 ; \mathrm{p}=0.000)$ and (Kendall tau $=0.216 ; \mathrm{p}=0.000$ ) (Spearman's rho $=0.312$; $\mathrm{p}=0.000)$, respectively.

\section{DISCUSSION}

The studies on periodontal health in Spanish military populations are scarce, conducted in military conscripts, ${ }^{9-12}$ without women and with a lower mean age than military professionals. ${ }^{13-15}$ 


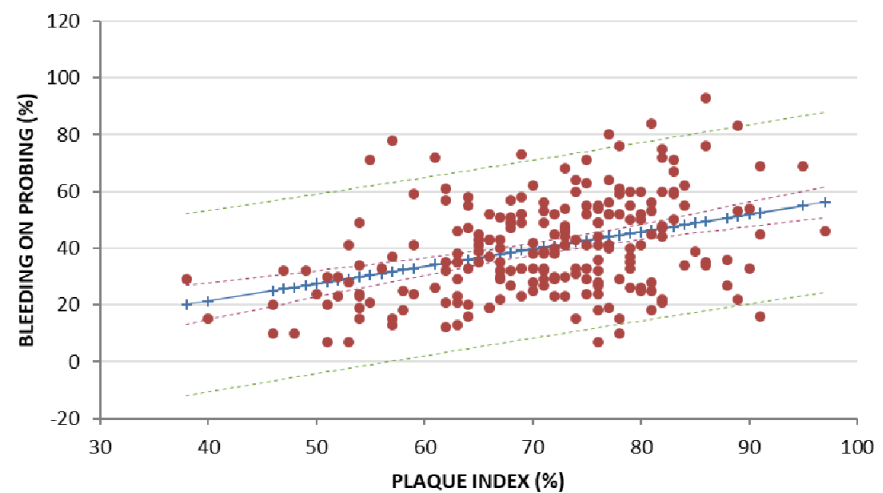

Figure 1 Dispersion diagram for plaque index and bleeding on probing. $R=0.383(p=0.000)$. $R=$ Pearson correlation coefficient.

In our study the prevalence of subjects with mild pockets was between 2.6 and 24.5 times higher, and the prevalence of subjects with severe pockets was between 2.5 and 27.2 times larger. The prevalence of loss of attachment was between 1.8 and 50.9 times higher in our study. Our severity, as the mean of sextants with superficial pockets, ranged from 4.9 to 10.8 times higher. However, deep pockets ranged from 8.3 times lower to 140 times higher.

Machuca et $a l^{11}$ obtained a mean probing depth 1.3 times less for each measure compared with the results from our study and Carroquino et $a l^{9}$ found gingivitis 2.5 times higher than that in our study. The highest values were found in the first upper molar and the lowest in the lower incisors. However, in our study, the teeth with the highest prevalence of gingivitis were the second upper molar and the second lower premolar, and those with the lowest prevalence were the upper incisors. In their study, periodontal pockets $>3 \mathrm{~mm}$ were rare. This differs from our results, obtaining a mean of 7.9 pockets $\geq 3.5 \mathrm{~mm}$ per person. Mombiedro-Sandoval ${ }^{13}$ found that the first and third sextants had the highest prevalence with periodontal pockets while in our study was the first.

We have chosen studies to analyse the periodontal health of foreign soldiers with an age cohort similar to ours. The prevalence of subjects with mild pockets was between 1.3 and 8.7 times higher in our study but with severe pockets ranged from 1.2 to 13 times larger. Regarding the mean of sextants per person, our mild periodontal pockets varied from 1.1 to 3.4 times higher, and severe pockets ranged from 6.9 times lower to 2.2 times higher. ${ }^{46-18}$ In military personnel of the Indian Air Force, ${ }^{19}$ they had a similar loss of attachment of 0 to $2 \mathrm{~mm}$ compared with our population, 1.4 times lower in those with 3 to $4 \mathrm{~mm}$ and 15.8 times higher in those with $\geq 5 \mathrm{~mm}$.

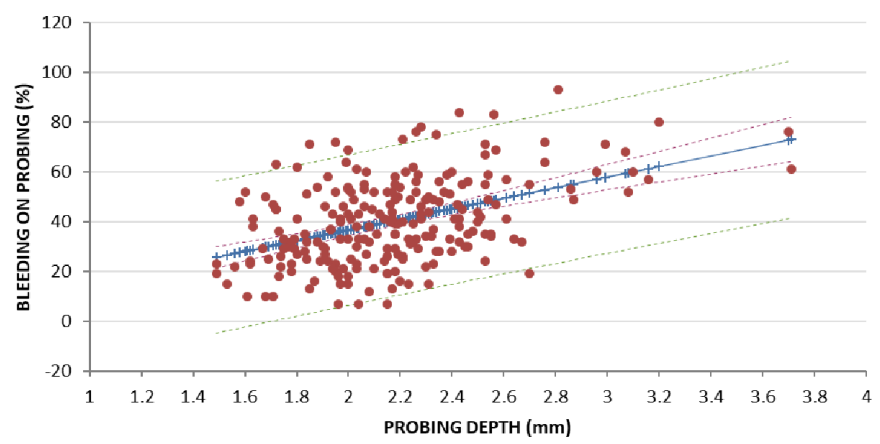

Figure 2 Dispersion diagram for probing depth and bleeding on probing. $R=0.453(p=0.000)$. $R=$ Pearson correlation coefficient.

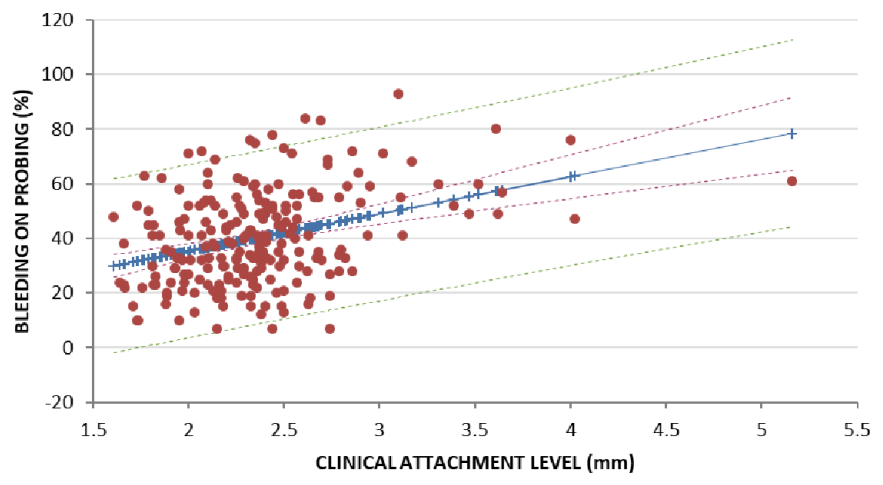

Figure 3 Dispersion diagram for clinical attachment level and bleeding on probing. $R=0361(p=0000)$. $R=$ Pearson correlation coefficient.

Other studies evaluated periodontal health in foreign military personnel with a young mean age ( $\leq 37$ years). The presence of mild pockets in our study ranged from 1.8 to 159.5 times larger, and severe pockets ranged from 1.2 times lower to 27.2 times higher. Only the Otero study measured clinical attachment level, finding that the subjects had 4.3 times lower of loss of attachment. ${ }^{20}$ Mean of sextants per person varied in mild periodontal pockets from 1.1 to 2.37 times lower compared with our population, and severe pockets ranged from 0.42 lower to 4.5 times higher. ${ }^{20-24}$ The study conducted by Röthlisberger et $a l^{25}$ in Swiss recruits found that the Gingival Bleeding Index was 1.5 times lower than that found in our study. In addition, the mean probing depth was almost identical to ours.

Finally, we recognise that there were limitations to our study. Establishing the pathological cut-off at $3.5 \mathrm{~mm}$ in the measurements and the inclusion of the third molars has influenced a greater periodontal condition, so our findings should be interpreted with appropriate caution. Future research would be advisable to study the impact of periodontal health promotion programme in Spanish Army.

\section{CONCLUSIONS}

The prevalence of individuals with periodontal pockets and loss of attachment based on the 2013 WHO CPI modified, as well as the severity of periodontitis, the O'Leary Plaque Index, and the Ainamo and Bay Gingival Bleeding Index were high in our military population. Periodontal disease compared with other studies in Spanish and foreign military populations was higher. However, differences in sociodemographic conditions and method comparison between authors require precaution when interpreting these findings.

This study was the first in Spain to explore periodontal health specifically in a representative sample of military professionals. The results obtained suggest inadequate oral hygiene and advise the need to improve periodontal health to reduce oral pathologies in military population both in national territory and areas of operations.

Contributors MBG, JMCP and PIAG contributed equally to the design, implementation of the research, analysis of results and writing of the manuscript.

Funding The authors have not declared a specific grant for this research from any funding agency in the public, commercial or not-for-profit sectors.

Competing interests None declared.

Patient consent for publication Not required.

Ethics approval The study was authorised by the Spanish Army and each participant signed and accepted a participant form prior to be involved. 
Provenance and peer review Not commissioned; internally peer reviewed.

Data availability statement Data are available upon reasonable request.

Open access This is an open access article distributed in accordance with the Creative Commons Attribution Non Commercial (CC BY-NC 4.0) license, which permits others to distribute, remix, adapt, build upon this work non-commercially, and license their derivative works on different terms, provided the original work is properly cited, appropriate credit is given, any changes made indicated, and the use is non-commercial. See: http://creativecommons.org/licenses/by-nc/4.0/.

\section{REFERENCES}

1 Teufer B, Sommer I, Nussbaumer-Streit B, et al. Screening for periodontal diseases by non-dental health professionals: a protocol for a systematic review and overview of reviews. Syst Rev 2019;8:1-12.

2 Dufty JR. BMJ Military Health 2014;160:17-8.

3 Breeze J, Gibbons AJ. Are soldiers at increased risk of third molar symptoms when on operational tour in Iraq? A prospective cohort study. J R Army Med Corps 2007:153:102-4.

4 Kovacević $\mathrm{V}$, Milosavljević M, Rancić N, et al. Assessment of the periodontal health and community periodontal index in the army of Serbia. Vojnosanit Pregl 2015;72:953-60.

5 Petersen PE, Baez RJ. Oral health surveys: basic methods. 5th edn. Geneva: World Health Organization, 2013.

6 O'Leary TJ, Drake RB, Naylor JE. The plaque control record. J Periodontol 1972;43:38.

7 Ainamo J, Bay I. Problems and proposals for recording gingivitis and plaque. Int Dent J 1975:25:229-35.

8 World Health Organization. Oral health surveys: basic methods. 4th edn. Geneva: World Health Organization, 1997.

9 Carroquino R, Llodra J, Fernández C, et al. Estudio epidemiológico de enfermedades bucodentales en una muestra de 200 soldados de la guarnición militar de Granada. Medicina Militar 1987:43:554-66.

10 García-Herranz N. Estudio del estado de salud bucodental y necesidades de tratamiento de los militares de reemplazo de la isla de Tenerife [dissertation]. Spain: University Complutense of Madrid, 1999.

11 Machuca G, Rosales I, Lacalle JR, et al. Effect of cigarette smoking on periodontal status of healthy young adults. J Periodontol 2000;71:73-8.
12 Briz F, Guembe C, Dordas S. Necesidades de tratamiento periodontal de la población militar Joven de las Fuerzas Armadas españolas. Medicina Militar 1993:49:594.

13 Mombiedro-Sandoval R. Estado de salud y necesidad de asistencia oral en una población militar [dissertation]. Spain: University Complutense of Madrid, 2010.

14 García B. Estudio epidemiológico de salud oral en una población militar de Sevilla [dissertation]. Spain: University of Sevilla, 2014

15 Tello M. Estudio epidemiológico de la salud bucodental antes y después de una instrucción preventiva en una poblacion militar (2006-2015) [dissertation]. Spain: University of Valladolid, 2018.

16 Katz J, Peretz B, Sgan-Cohen HD, et al. Periodontal status by CPITN, and associated variables in an Israeli permanent force military population. J Clin Periodontol 2000;27:319-24.

17 Ahuja A, Darekar HS. Community dentistry in armed forces. Med J Armed Forces India 2003:59:18-20.

18 Khalilazar L, Khoshdel AR. Oral health profile in Iranian armed force: focusing on prevention strategies. Journal of Archives in Military Medicine 2016;4:e39275.

19 Thankappan P, Kaushik S, Gupta S, et al. Periodontal diseases in military aviation crew: a pilot study in armed forces. J Int Clin Dent Res Organ 2015;7:116-21.

20 Otero J, Proaño D. Prevalencia de enfermedades periodontales, factores de riesgo y necesidad de tratamiento en el personal de tropa masculino en Servicio Militar en Lima en el año 2000. Revista Estomatológica Herediana 2005;15:11-17.

21 Senna A, Campus G, Gagliani M, et al. Socio-economic influence on caries experience and CPITN values among a group of Italian call-up soldiers and cadets. Oral Health Prev Dent 2005;3:39-46.

22 Pérez CD, Castillo AC. Determinación de la necesidad de tratamiento periodontal en jóvenes de Una escuela militar. Revista Cubana de Medicina Militar 2008;37:1-8.

23 Villota DD, Cardona M, Vivas J, et al. Prevalencia Y factores relacionados Con caries Y periodontopatías en Los cadetes de la escuela Militar de Aviación. Journal Odontológico Colegial 2009;4:55-60.

24 CLÁ C, Jaimes VR. Prevalencia, severidad Y necesidad de tratamiento de la enfermedad periodontal en personal del Batallón de Artillería de Defensa Aérea No. 2 Nueva Granada. UstaSalud 2013;12:11-19.

25 Röthlisberger B, Kuonen P, Salvi GE, et al. Periodontal conditions in Swiss army recruits: a comparative study between the years 1985, 1996 and 2006. J Clin Periodontol 2007:34:860-6. 